NORDISK MUSEOLOGI $1995 \cdot 1$, S. 53-62

\title{
ART ON TyNESIDE
}

\author{
John Millard
}

Many people will not visit art galleries because they think they are boring, and that art is not meant for them. In Britain, and I believe in Nordic countries as well, art has been made the preserve of an educated elite and the majority feel excluded from its mysteries.

Distrust of art and lack of interest in art galleries has even been encouraged by art curators and art historians. It is as if we have conspired to ensure that art galleries are unpopular, and this is a situation which is of course wholly unacceptable to someone like me who is paid by a local council and who believes that art has an important role to play in people's lives. As curator of the city art gallery, I do not work for an educated elite but for all the people of Newcastle.

One of the tools which we art curators use to put people off art is the way we display art. We have developed a very intimidating way of showing paintings which is designed to emphasise their formal qualities. Paintings are well spaced out on long white walls in huge rooms, with «room to breathe» and minimum «interference» from other things around them. This way of displaying art is now accepted as the norm, and variations are treated with contempt, but it is only a recent and rather unusual method of display. Art can also be shown in a more friendly way, and with more understanding of how things were shown in the past.

The Laing Art Gallery in Newcastle upon Tyne is the main art gallery in the North East of England. It was founded in 1901 and opened in 1904. It is a fine
Edwardian building, but it is capable when necessary of providing galleries that look like big white boxes to show modern art. The exhibition The Experience of Painting in 1989 was of large contemporary British abstract paintings which are meant to be shown in this way. But we also took care to provide a friendly carpeted room with chairs and books, photographs and displays of material from the artists' studios.

Other contemporary artists need a completely different sort of display. The artist Jim Whiting makes big installations with numerous figures which are powered by compressed air and bounced around the galleries at the Laing Art Gallery.

The Art on Tyneside display which opened in July 1991, shows pottery, glass, paintings, silver and costumes in recrea- 


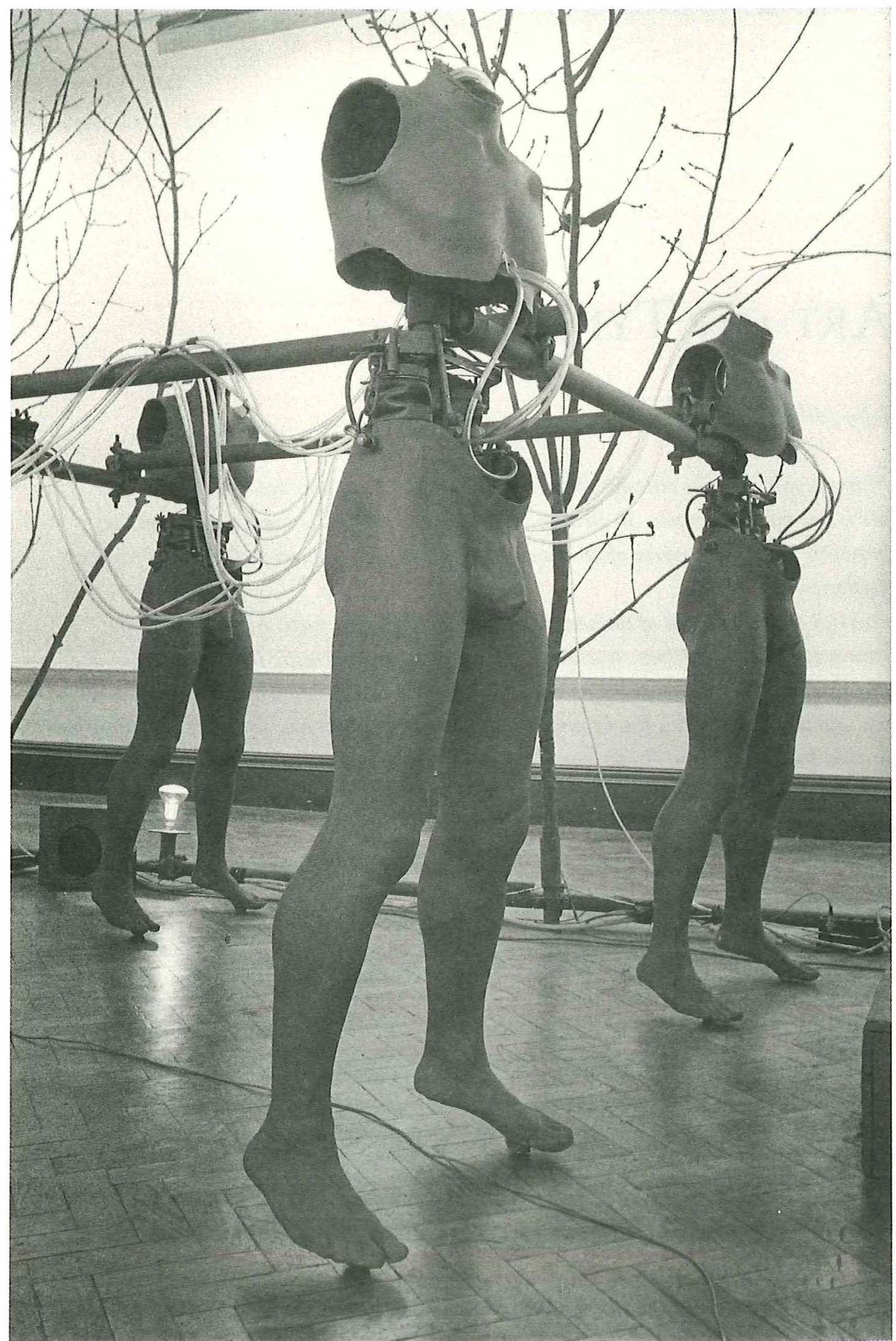

Part of a kinetic installation by the artist Jim Whiting at Laing Art gallery. 
tions of rooms, with models, interactive exhibits and information putting them into context. It was meant to attract some of the many people who believe that art galleries are not for them, and it has increased the gallery's visitor numbers by $38 \%$.

Two other important new art displays which opened in England in 1991 were a new extension to the National Gallery in London, which shows Renaissance paintings, and a re-display of fine and applied art collections in Kelvingrove Museum and Art Gallery in Glasgow.

The National Gallery extension cost $£ 35$ $1 / 2 \mathrm{M}$. given by Lord Sainsbury and his brothers Simon and Timothy Sainsbury, and the architect was Robert Venturi of the Philadelphia firm of Venturi, Scott Brown and Associates. To reach the paintings, visitors must trek along immense corridors to the lifts or up huge grey staircases where the names of great Renaissance painters are carved in letters of heroic proportions. The galleries are Victorian in spite of their modern details, and the Sainsbury Wing is an elevated temple of the arts. Even before the visitor gets to the art it has been put out of reach on a pedestal, and this is particularly inappropriate for the little domestic devotional paintings from northern Europe. Such paintings need an intimate and friendly setting, and do not look good in an environment so divorced from everyday life.

In Glasgow, art from different periods and in different media was brought together in new displays with the themes Classicism, Realism and Spirituality. Curators made a real attempt to break away from art historical approach which would appeal only to the specialist, but the result conforms to the powerful con- ventions of modern art gallery display. Instead of taking a great leap of the imagination, in the end the curators took only a tiny step.

It occurred to us that historical displays might help to shake loose these modern display conventions. An exhibition of work by a Victorian artist in the North East of England (Ralph Hedley: Tyneside Painter, 1990-1), used a historical style of presentation to make it feel more friendly and attractive. The entrance was like a fairground stall, and through it was a dark tunnel with photographs and sound effects. On the other side of the tunnel, the paintings were presented in Victorian style, as if the visitor had gone back in time to a Victorian gallery. People enjoyed this bit of drama and the pictures were shown more as the artist originally intended, crowded together with many double hung.

Late in 1991 an exhibition Palaces of Art, which opened at Dulwich Picture Gallery in London and then travelled to the National Gallery of Scotland, took the history of art displays as its subject. It was evidence of an increasing interest in how art had been shown in the past, and revealed how often in the past paintings were meant to be part of the furnishing of an interior rather, than to be seen in isolation.

Recent research has given more information about how art was shown in Newcastle in the past. Newspaper pictures of a Polytechnic Exhibition in Newcastle in 1848, show an extremely lively style of display, with paintings shown crammed together in ornate interiors, along with stuffed birds, fountains, a miniature canal with model ships and many other things. 
JOHN MILLARD

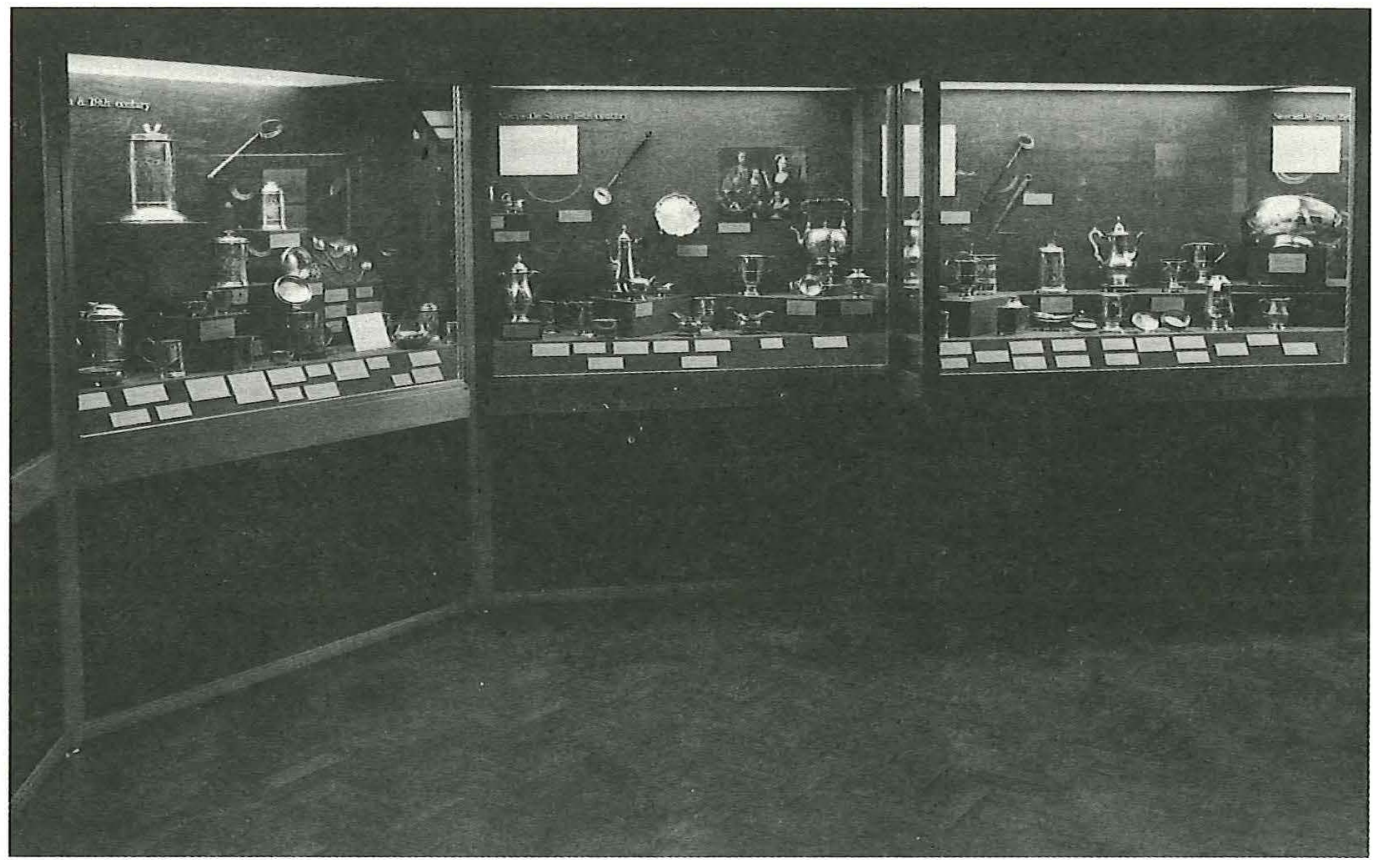

18th. century Newcastle silver in a traditional display, now replaced by 'Art on Tyneside'.

In 1870 the Central Exchange Art Gallery was opened in the middle of Newcastle. One of its owners Thomas Pallister Barkas was an expert in everything from spiritualism to stenography, and his wide range of interests was reflected in the Gallery's programme. He put on concerts, displays of ghostly apparitions, and travelling acrobats, as well as art exhibitions.

Rich local art patrons and collectors started an exhibition organisation in 1878, called the Arts Association of Newcastle upon Tyne. It was intended to show art with a loftier tone, but it lasted only a few years, and in 1883 it was replaced by a society organised by artists and called the Bewick Club after the Tyneside master wood-engraver Thomas Bewick.
Through the Bewick Club, local painters dominated the artistic life of the city for over twenty years. Their classes, outings and annual dinners were run like a jovial men's club, and their exhibitions showed paintings stacked up the walls in an informal mixture of work by amateur and professional artists.

The era of the Bewick Club in Newcastle was finally ended with the opening of the Laing Art Gallery, which quickly became the main exhibiting centre in the city. Early photographs show the Victorian style of hang and the liberal use of plants in the hallways.

From the beginning the Laing Art Gallery collected pottery, glass, costume and metalwork, as well as paintings and 
sculpture. By the 1970 s works of art in different media were shown in separate areas. There were separate displays for silver, glass, ceramics, watercolours and costume, all in sets of cases with the galleries blacked-out above them. These austere displays were really only of interest to a small number of collectors, and they were designed to reflect the way that museums are organised rather than the visitors' requirements.

The Victoria and Albert Museum in London had departments of Ceramics,
Metalwork, Textiles and so on, and was the model for curation and display of collections throughout the country. It did not matter whether these distinctions were useful to the visitor. There were administratively convenient and that was enough.

Art on Tyneside was to bring all these collections together in one coherent display which would appeal to wider audiences. The needs of potential visitors were of prime importance in the design of the display. As soon as possible the designer, Laury Redman of Redman Design Associ-

The entrance to the 'Art on Tyneside' display, with a mural by the artist Barrie Ormsby and a team of Tyneside people.

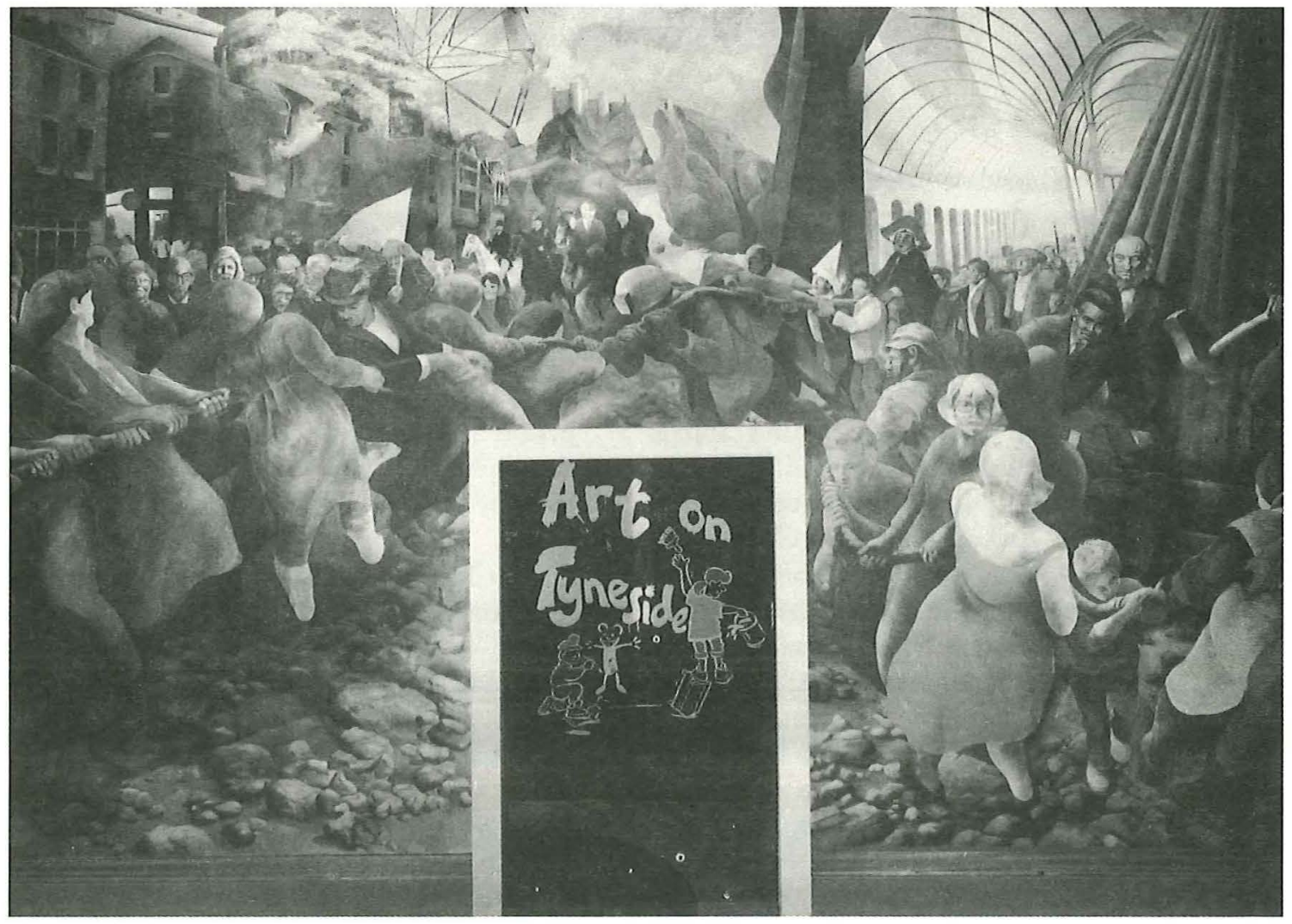




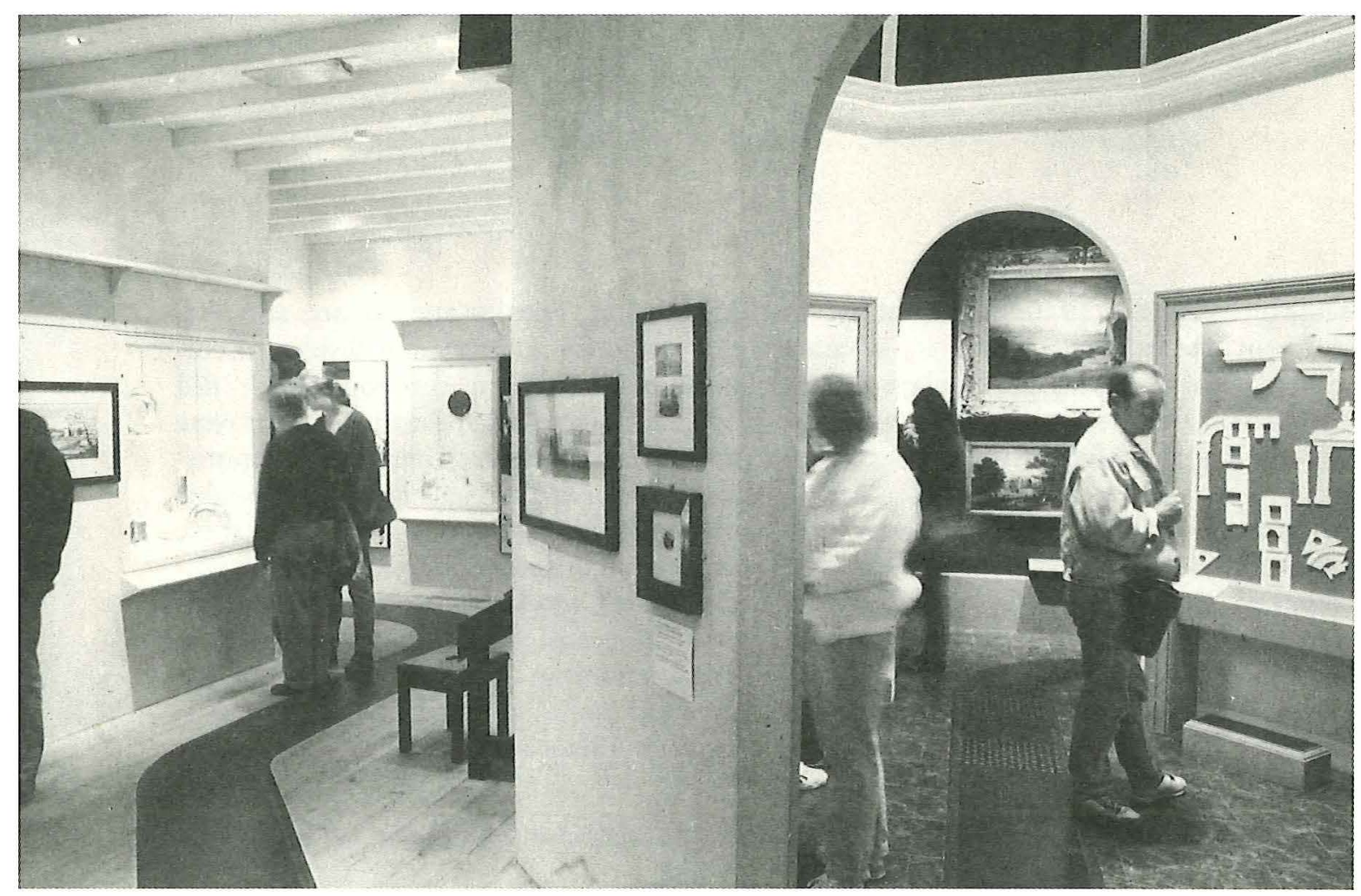

The black floor track is designed for visually-impaired visitors, and on the right visitors can design a classical building using magnetic pieces.

ates, produced a model of the display which was shown to a group of disability consultants. They produced a detailed report on what would be needed to cater for people with a range of disabilities. At the same time the Laing's education officer was discussing the display with teachers so that the display would appeal a new audience of 8-12 year old children.

The display itself is introduced by a mural by the artist Barrie Ormsby who worked with a group of Tyneside people. It is large and colourful and contains numerous portraits of Tyneside artists, writers, and famous local characters, together with many local buildings and monuments.

At the entrance door are two cartoon characters, the children Tom and Rosie, who appear throughout the display. They travel with the visitor back 400 years to begin a trip through a chronological series of rooms. They appear in cartoons in each room in the display and help visitors to use interactive exhibits. Text in each room tells the story of art in its historical context in a total of about 1,500 words. There are leaflets giving the text of these panels in Gujarati, Urdu and Cantonese, the main languages apart from English used by residents of Newcastle.

The paintings, prints, watercolours, glass, silver, costume and ceramics are set in historical settings, like an 18th century coffee shop, craft workshops, and a Victorian gallery. The rooms gradually get bigger through the display to give the impression, without using words, that more was happening as time progressed and more different types of art-works were being produced. The Victorian art gallery is based on the Central Exchange Art 
Gallery in Newcastle, and has large mirrors to give the impression of an immense space. A figure representing Thomas Pallister Barkas begins a slide show as visitors walk in and are picked up by an infrared detector.
Throughout the display there are interactives which keep the interest of children. At one of them, visitors design a decorated glass goblet; at another the parts of a classical facade are arranged on a magnetic panel. There are also buttons to press to
The 'Talking Tugboat' gives the answers to $a$ quiz for children. Above is a scale model of Newcastle's most famous landmark, the Tyne Bridge.

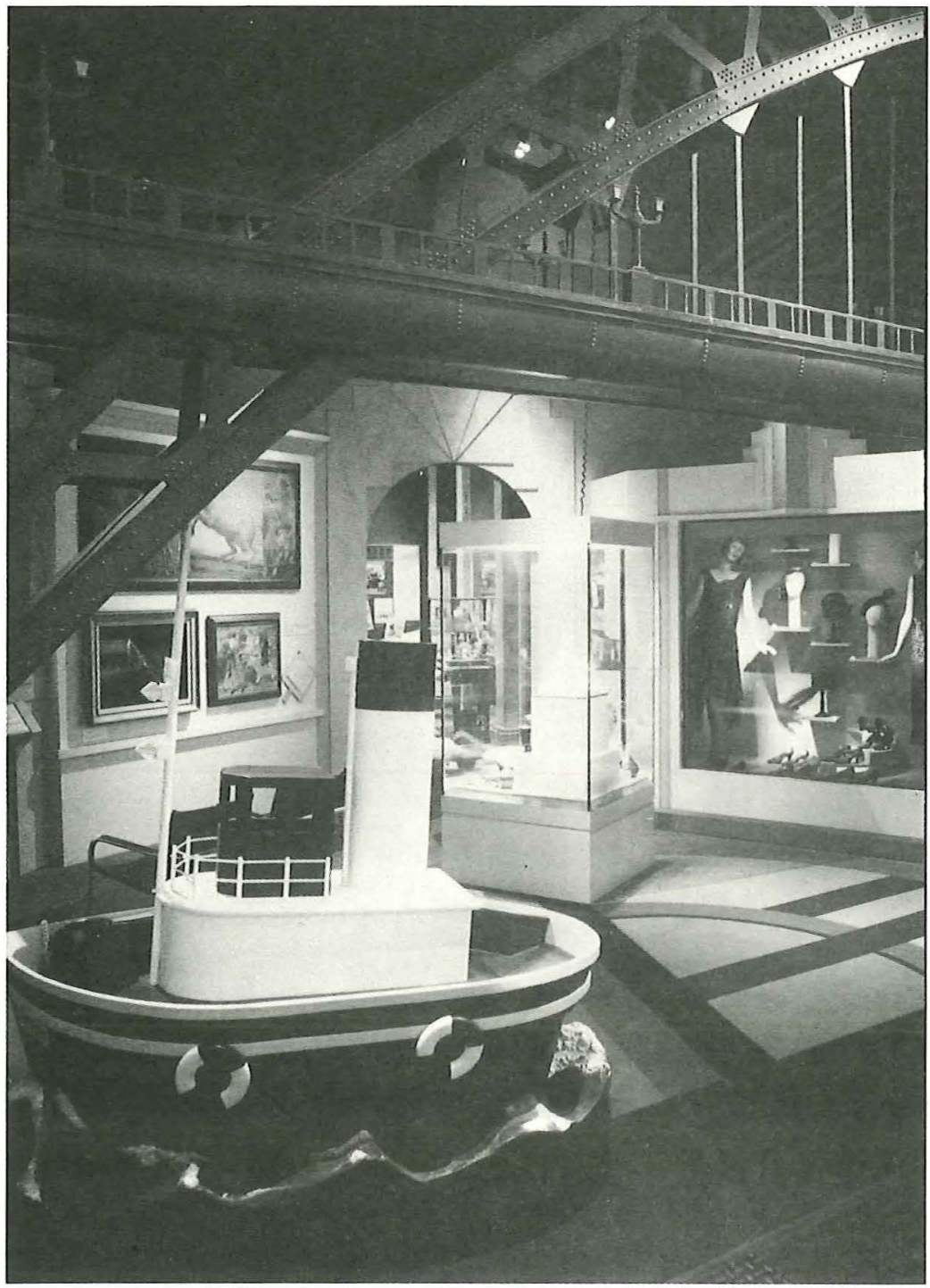




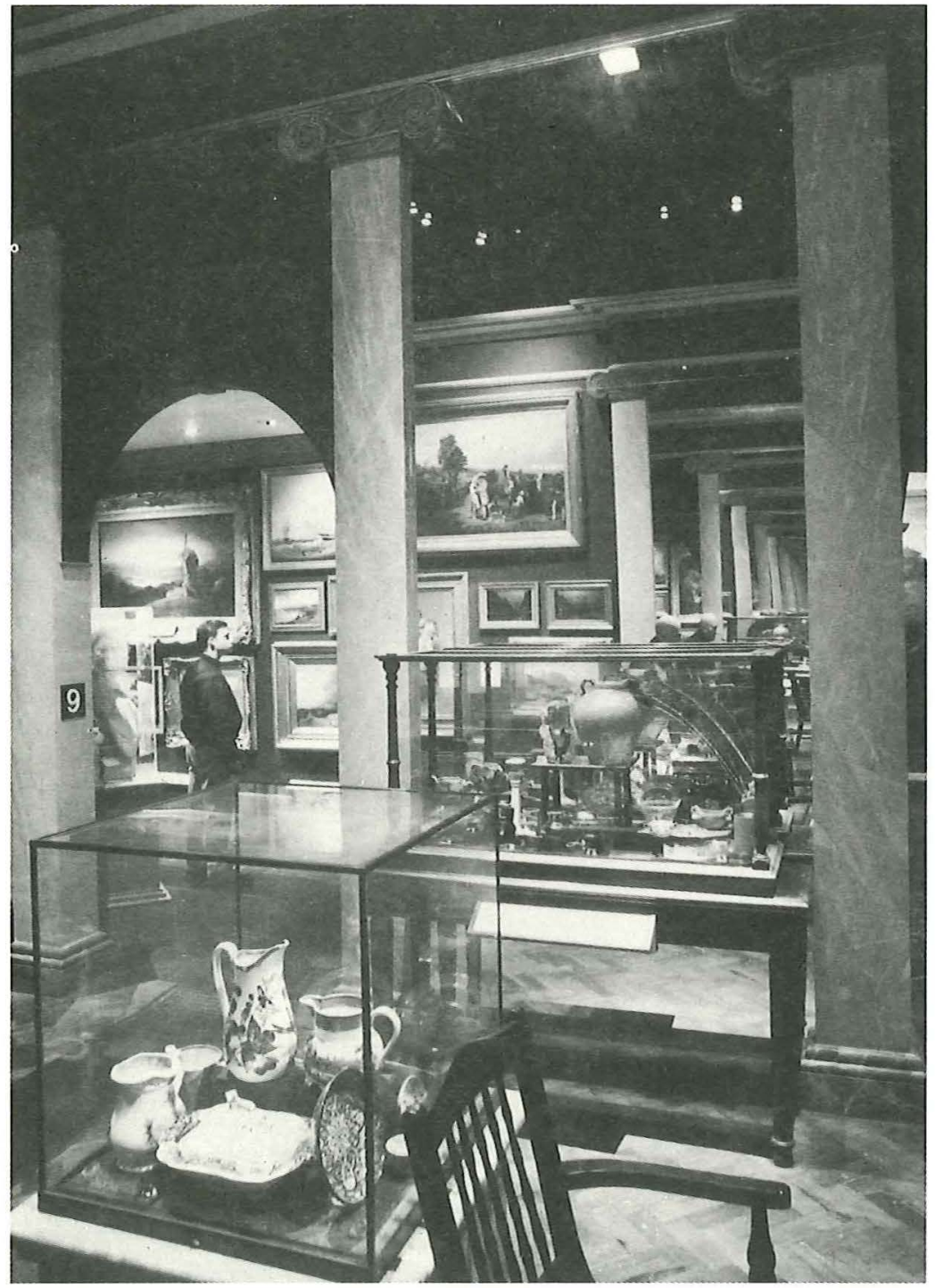

On the opposite page: Prints and paintings hang on the walls of the 18th. Century Coffee Shop.

Mirrors give the impression of extra space in the Victorian Art Gallery.

activate short videos giving contextural images and music of the 1920s and 1930s. An innovative rubber floor track was developed for visually-impaired visitors. It can be used with a tape guide which takes visitors round the display pointing out special features like a Braille version of an 18 th century newspaper, and three "Thermaforms", sculpted versions of pictures designed for blind people.

In one of the later sections is a "Talking Tugboat» which has three telephones. On 


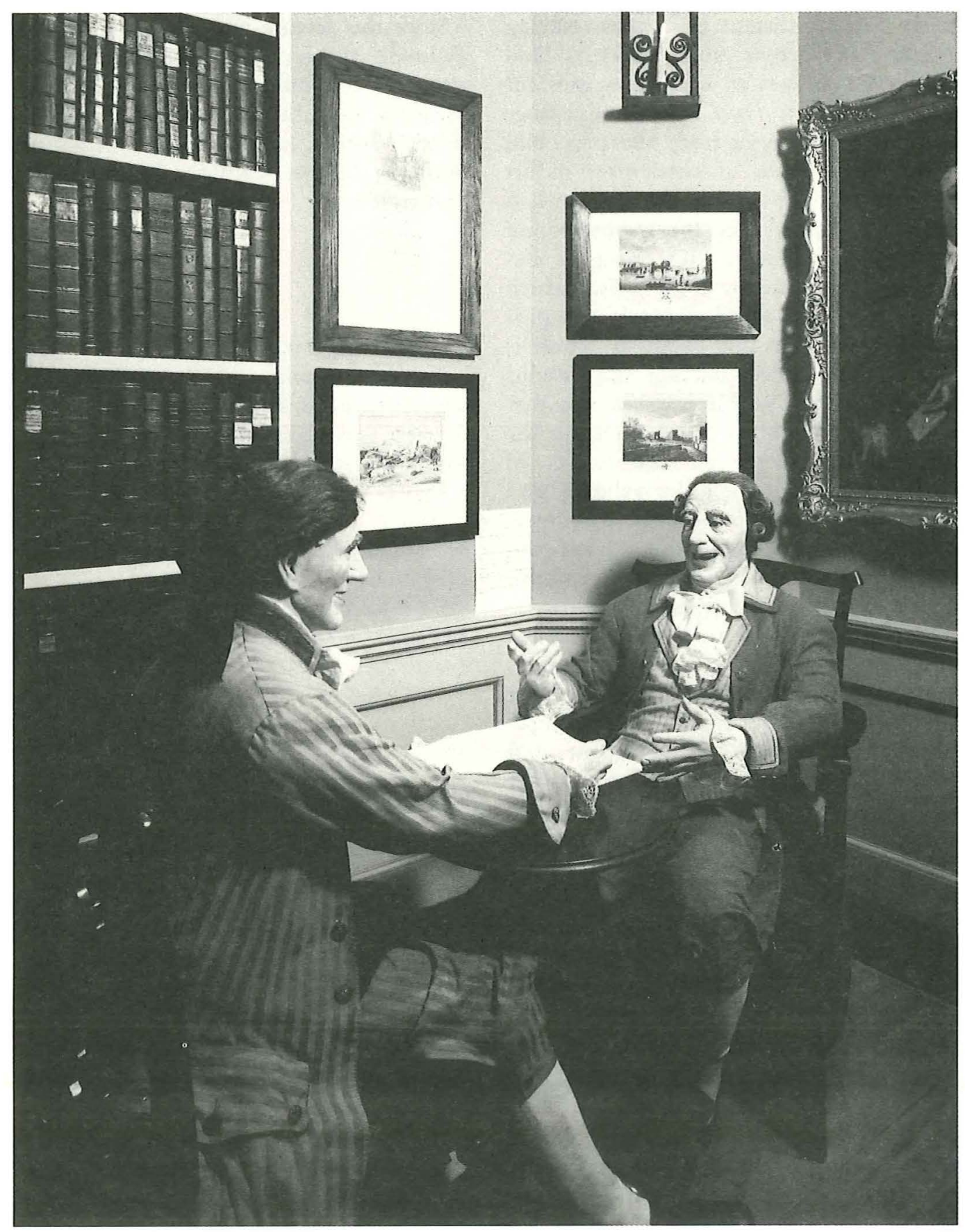


62 them visitors listen to actors playing artists, craftspeople and architects and giving the answers to a role-play quiz for children. Art on Tyneside also emphasises that art is not only from the past, and encourages people to participate in art activities. At the end of the display is a small exhibition area for contemporary work from Tyneside, with changing displays of sculpture by local artists which visitors are encouraged to touch, and projects from schools and hospitals. There is also a short video starring the famous Tyneside actor Tim Healy explaining that there is a lot of art to see outside the Laing Art Gallery, on the streets of Tyneside and in other art galleries and museums. He points out fine buildings, churches and public sculpture, and encourages visitors to try out painting, embroidery, pottery or some other art activity.

In the year that Art on Tyneside opened at the Laing Art Gallery, visitor numbers increased by $38 \%$, and many visitors have commented on the more friendly atmosphere. The uniforms of attendant staff have been changed from a formal jacket and tie, to a "polo» shirt with a logo embroidered on the chest. A café has also helped to make the gallery feel more accessible.

On 19 August 1992, the Newcastle Evening Chronicle published a guide to museums in the North-East of England giving each a rating for its appeal to adults and to children. The Laing Art Gallery was the only museum to get a top score in both categories. It is surely unusual for an art gallery to outstrip all other sorts of museum in its appeal to both adults and children. It is certainly the first time the Laing Art Gallery has won a popularity contest.
Since this lecture was given the Art on Tyneside display has won a national award, The Gulbenkian Award for the Museum with the Best Provision for Disabled Visitors, and a British Telecom Award as the best exhibition in the NorthEast region.

\footnotetext{
* This paper was first presented at a seminar, «Stage performance Exhibition", held by the Danish Museum Training Institute in Holstebro,

Denmark, September 1992

All illustrations provided by the Laing Art Gallery.
}

John Millard er kunsthistoriker og Senior Curator ved Laing Art Gallery, Newcastle.

Adr: Laing Art Gallery, Newcastle upon Tyne

NE1 8AG, UK(England). Fax +44-912220952 